\title{
The Role of TPQ (Educational Garden of Qur'an) on Children's Mental Development Toward Civil Society (Madani Society)
}

\author{
${ }^{1 s t}$ Ana Andriani \\ Universitas Muhammadiyah Purwokerto \\ ana.andriani@gmail.com
}

\author{
${ }^{2 n d}$ Badarudin \\ Universitas Muhammadiyah \\ Purwokerto \\ badarudin@ump.ac.id
}

\author{
${ }^{3 r d}$ Agung Nugroho \\ Universitas Muhammadiyah Purwokerto \\ agungnugroho@ump.ac.id
}

\begin{abstract}
Globalization gives birth to advanced science and technology products that on the one hand can facilitate the work and fulfillment of human needs, but on the other hand can cause adverse effects. This condition occurs because of cultural shock (cultural shock) which resulted in ethical erosion, moral degradation, and decadence behavior, especially among the younger generation. The most important factor in the preparation of the younger generation in the future is the mentality that must be built as early as possible. Mental development is not an easy thing, but it is also not difficult if done gradually and sustainably. Consistency of all elements of society is believed to make children ready to face the future towards civil society. This paper will discuss the importance of building the mentality of the young generation to form a civil society. Some problems, indicating bad things will be more severe if not anticipated by preventive action for the good of the future. The alternative solution offered is the implementation of a Qur'an Educational Place (TPQ) which is expected to give a good understanding of religious values. How the methods, strategies, and application of implementation will be discussed in this paper.
\end{abstract}

Keywords: TPQ, Mental, Civil Society

\section{INTRODUCTION}

Various life changes occur as a result of globalization, both from ideological, political, economic, socio-cultural, defense and security aspects. Factors causing these changes are numerous, among them the development of information technology that leads to acceleration in information, telecommunication, transportation, which seems to make the world without boundaries. Anticipation of the things that are not desirable need to be maximized. especially its impact on the young generation who will holding the baton of relay life, nation and state of indonesia in the future.

Ohmae, K. (1991) states that: "... globalization brings not only a global ideology, in this case liberal democracy among the world population, but also threatens the process of nation-state formation, because globalization essentially wants to create a country without boundary (borderless) ". Globalization becomes an alarming phenomenon that is reasonable because of the changes of life that do not always lead to better things, especially the impact on children who are still vulnerable to receiving various onslaught of products, because its commonness.

Education became one of the important alternatives undertaken in building the mentality of the nation's children. Henderson (1959: 44) interpreted education as: "a process of growth and development, as a result of individual interactions with the social environment and the physical environment that lasted throughout life since human birth. The family becomes the main pillar of education to build the mentality. This can be interpreted that the family becomes the best education center. Drijarkara (1964: 64), meaning education in the family as:

1. Education is living together in unity, fathermother-child, where there is a process of humanizing children. He proceeds to humanize himself as a perfect human being.

2. Education is coexisting in unity, father-motherchild, where there is a process of child culture. He proceeds to finally be able to entrench himself as a perfect human being.

3. Education is living together in unity, fathermother-child, where the exercise of values, by which he proceeds to finally be able to carry out himself as a perfect human being.

Education is the responsibility of parents, namely the father and mother who is a central figure in education. Father and mother are responsible for helping to humanize, cultivate, and instill value to their children. The guidance and assistance of the father and mother will come to an end if the child becomes an adult, becoming a perfect human being. Parents' educational background, parental parenting, socioeconomic status, and the environment in which students live make students different from each other.

Mentality is the most important factor in the preparation of young people in the future that must be built as early as possible. Mental development is not an easy thing, but it is 
also not difficult if done gradually and sustainably. Consistency of all elements of society is believed to make children ready to face the future towards civil society. The onslaught of western culture such as secularist, pluralist, liberalist, hedonist, and communist ideals do not make them afraid, when the development of a strong mentality is continuously done. The mentality that is built is a Muslim mentality that is loaded with Islamic values. So that not only the pursuit of the world, but still broad-minded in order to reach the future to get from the willingness of God is the ultimate goal.

There are many strategies, techniques, methods, which can be done by all people in order to avoid the bad effects of globalization. Besides the family as the main pillar of education, one of the methods that can be done is to build the Qur'an Educational Place which is considered capable of giving understanding to the children children of a certain age on ethics, values, morals, norms, and the importance of interpreting and practicing good behavior and sholeh according to the guidance of the Qur'an and AsSunnah. The facts say that the erosion of Islamic spiritual values resulting from the misleading transformation of western culture severely damages the mindset of children. Games from advanced communication tools, such as mobile phones, tablets, gadgets make them forget the time to carry out its main task of learning. Addiction games on line is rampant happened, even can appear in adulthood.It does not necessarily happen, but the act of allowing the family to do as the nearest environment fatal impact.Children who should be excited and eager to run the role as a student to reach the period crucial front eroded by sophisticated products that actually are not so they need so much. The number of undesirable behaviors caused by a weak mental continues to increase significantly from year to year.

A good Muslim has a light duty, referring to Surat AliImran verse 104 which means " And let there be (arising) from you a nation inviting to (all that is) good, enjoining what is right and forbidding what is wrong, and those will be the successful ", so we should always remind each other. Caring must be raised with positive behaviors to anticipate things that are categorized can be even worse. We do not want to let the next generation of the nation, especially children from year to year experience spiritual destruction, mental damage, even forget with his own religion. If that continues, how many children who can not read and write the Qur'an, suffered mental damage, even dared to the parents and never think of his future with the loss of spiritual values on the soul of the child. Things that do not want the age of children who have dared to consume drugs, commit acts of crime, and immoral actions against fellow friends and others. This becomes a challenge for all of us.

Prevention efforts can be done with mental spiritual coaching, parental guidance and the planting of religious values from an early age that is very necessary to be implemented for the future of children to our grandchildren as the nation's successor. For us a Muslim and a student, for the role and overcome it is through the development of a sense of love with the handle and the principle of our lives is none other than the Qur'an. The door to be able to conduct guidance with the Qur'an is by understanding the Qur'an, loving the Qur'an, and then practice the content of Qur'an content. There is a hadith which means "the best servants are those who study the Qur'an and teach it". It can be realized with the existence of reading Qur'an for children who are accommodated by the effort of established an educational institution in the form of Qur'an Educational Place or abbreviated TPQ. The existence of these educational institutions, presumably become the spirit and glory are essential to be able to become someone who has spiritual and religious knowledge. Our efforts are to be able to participate in the development of the generation of children, spiritual mental development, and the planting of religious values.

TPQ which has a mission to improve the mentality of children to fortify themselves from the destructive and misleading western culture is very important to be held. Researchers are interested to hold and organize TPQ in Tambaksari village for children to create an atmosphere of reading and learning activities of Qur'an. Meeting the spiritual education needs of children is expected to be achieved. Researchers chose the theme " The Role of TPQ to Build Mental Children towards the Civil Society ".

Many children who can not read and write Qur'an, a phenomenon of concern that should be taken preventive measures as mentioned above. Estimates are 50\% more children are forced not to receive Qur'anic education, this is due to the unfamiliarity of the Qur'an Educational Place (TPQ). The role of village government that can encourage the establishment of the Qur'an Educational Place (TPQ) is necessary. It is unfortunate when they see the enthusiasm of children who still have the desire to continue learning, both learn about the general material and religious materials but the infrastructure does not exist. Religious values on reading and writing of the Qur'an are the main guidelines for a Muslim. So there needs to be a procurement and the implementation of Educational Place Qur'an (TPQ) in order to facilitate and accommodate the enthusiastic children who have the desire to learn to read and write Qur'an.

\section{DISCUSSION}

1. The meaning of TPQ (The Education Park of the Qur'an) and its Role.

One of the most important aspects of human life is Education. Islamic education becomes an integral part of the Muslim community. The Qur'an and the Hadith of the Prophet Muhammad. Being the main foundation of the 
education. Of these two sources by Muslim intellectuals have been developed and classified into two parts: First, aqidah for teachings relating to faith; second, is sharia for teachings related to real charity. Philosophy becomes a complement that functioned as a tool in human thinking to always develop the knowledge already in possession, and used to know the problems that are faced and how to solve the problem without causing bigger problems. The development of human civilization can not be separated from the religious values derived from the Qur'an and AsSunnah, because we believe that religion is the main source and occupy the highest position followed then is the philosophy, then science.

Ideally, the Qur'an and As-Sunnah become inseparable in the life of the Muslim Ummah. including in education, both formal, nonformal and informal. Education is the responsibility of all parties, in addition to parents, community, government and private. All are responsible for the benefit of education itself for the good of the next generation. All components synergize, because the best people are he who is able to contribute to the surrounding community. And command to teach science even one verse. Quran Surah Lukman 31 (QS 21: 12-15)

And We had certainly given Luqman wisdom [and said], "Be grateful to Allah ." And whoever is grateful is grateful for [the benefit of] himself. And whoever denies [His favor] then indeed, Allah is Free of need and Praiseworthy.

And [mention, O Muhammad], when Luqman said to his son while he was instructing him, "O my son, do not associate [anything] with Allah. Indeed, association [with him] is great injustice."

And We have enjoined upon man [care] for his parents. His mother carried him, [increasing her] in weakness upon weakness, and his weaning is in two years. Be grateful to $\mathrm{Me}$ and to your parents; to Me is the [final] destination.

But if they endeavor to make you associate with Me that of which you have no knowledge, do not obey them but accompany them in [this] world with appropriate kindness and follow the way of those who turn back to Me [in repentance]. Then to Me will be your return, and I will inform you about what you used to do.

The above verse explains that the most emphasized education is education conducted by parents. because in education consciously or unconsciously is the first education obtained by a child before getting influence from outside. But if the parents tell us to do things that are forbidden in religion, then we must reject it, but with a good word. The basic principles of Islamic education materials consisting of aqidah, worship, morality, and muamalah become provisions in living the life of a servant to the Rabb.

The family as an important component in providing basic education to children, can be done in parallel with education outside the home. Formal out-of-home education is expected to provide more insight for children in their social relationships. TPQ (Taman Pendidikan Qur'an) becomes an alternative educational institution to provide education and guidance on religion. The understanding of TPQ is the Education Park Qur'an (TPQ) can be interpreted as an educational institution or teaching Islam for elementary school children (6-12 years old) which makes students able to read the Qur'an is good and true as the main target. The foundation of Quran Educational Park (TPQ) is Qur'an and As-Sunnah, and halaqah Ulama. The Qur'an in surrah Al-Qamar [54] verse 17 explains that: " And We have certainly made the Qur'an easy for remembrance, so is there any who will remember?" Furthermore, in surah Al Haqqah (69) verse 48 : " And indeed, the Qur'an is a reminder for the righteous."

The verses of the Qur'an above can be interpreted that how the Qur'an is as a lesson that can provide enlightenment for the people who are cautious. This condition can be done in synergy both within the family, community, government and private parties and other parties. Rasululloh, peace be upon him said:

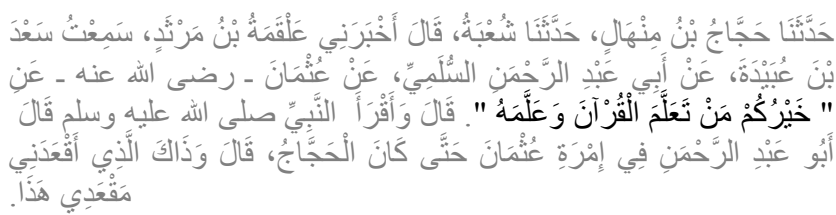

The Prophet (aلdyadsaid, "The best among you (Muslims) are those who learn the Qur'an and teach it." (HR Bukhori). This can be interpreted that the best person is the one who wants to study the Qur'an and teach it. The Qur'an as the guideline of perfect life, as in the halaqh Ulama stated that: "how it is said by Ibn Kholdun and Ibn Sina that the teaching of the Qur'an should be given the first priority that is taught to the children". How important the educational intake for children so that the Qur'an should be prioritized. The purpose of the Delegation of the Qur'an 
Education Park (TPQ) in its area is to prepare the students in order to become the Qur'anic youth generation. Commitment with the Qur'an and make the Qur'an as a reading material and view of life in daily activities.

\section{Mental Concepts}

There are several definitions of mental, although there is no certainty about the definition of psychologists. Etymologically the word "mental" comes from the Greek language which has the same meaning with the understanding of psyche, meaning psychic, soul or psychological. Mental can also be sourced from the Latin word of mens or metis which means soul, soul, soul, spirit, spirit. Mental understanding above can be interpreted as matters relating to psycho or psychiatric that can affect individual behavior. Any behavior and expression of individual movements is a boost and a reflection of the mental state. Draver J (t.th: 196) mentally mentally that is "revering to the mind". This is interpreted as something related to the mind or mind itself. Mental is not physical but more to something that is inner nature and character.

Mental conditions can be divided into two forms, namely a healthy mental condition and unhealthy mental state. A healthy mental condition will certainly bring out normal individuals. A normal person is a form of individual behavior that does not deviate from the behavior in general where an individual is living, and a normal person will exhibit a harmonious and appropriate behavior (adequate) and acceptable to society in general, where the attitude of his life is in accordance with norms and patterns of living environment. In simple terms the individual is able to adapt naturally.

Unhealthy mental condition will form an unhealthy personality also (abnormal), then should get attention from the surrounding environment. An unhealthy person (abnormal) is the presence of a person or individual that is very striking and very different from the general behavior that exists in the environment, or also called abnormal behaviors (abnormal). In general, unhealthy mental form that is relatively can be seen in individuals away from the ability to adapt or always have difficulty in adapting, and has the character of being inferior and superior.

The barometer of any individual behavioral disorder is its mental state. Daradjat, Z (1990: 16) explains that a healthy mental will determine his response to every problem, and the ability to adapt, and mentally healthy that determines whether a person or individual has a passion or they are passive and uninspired and even have fear to live. Someone is said to be mentally healthy or not, can be seen from his daily behavior. It is not easy to know someone is mentally disturbed or not. but the measure is to feel ourselves how far the state of our feelings whether it has exceeded the limits of reasonableness or not, sadness, disappointment, pessimism, low self and others as. Daradjat, Z. (1990: 16) explains that: a person or an individual who is disturbed by his mental health, can be seen in his actions, his behavior or the expression of his feelings, because a person or individual who is mentally disturbed is when there is emotional shock, behavioral disorder or action. The mental meaning of some of the above statements, is the things that are within a person related to the psychological that can encourage the behavior and form the personality. Conversely, a healthy mental will give birth to behavior and a healthy personality as well.

\section{The Concept of Civil Society}

Civil society can be interpreted as a city society that has a commendable behavior based on Qur'an and As-Sunnah. The concept of Civil Society refers to Madyayyah society. Shaykh Mustafa Al-Ghalayini (1976: 110) explains in the book "Guidance Toward the Noble Virtue" explains the concept of Civil Society or modernity that haq and true is a behavior or acts that make man who claimed to be a modern person, has a healthy body, reasonable minds, and good morals. Anwar Ibrahim explains the concept of "civil society" as a translation or Islamic concept of "civil society", whereas in the concept of Islam, madani means civilized society, upholds human values, advanced in the mastery of science and technology. Civil society became the symbol of idealism expected by every society.

History explains there are two civil society in history which is documented as civil society ie Saba '(Saba'), and Medina society after tractate, Medina agreement between Rasullullah SAW and Moslem with Jewish people of Madinah and Watsani from Aus and Khazraj.

Madani is etymologically, meaning city society. Nevertheless, the term city does not refer solely to geographical location, but rather to certain characters or traits that are suitable for the inhabitants of the city. Civil society does not come from an urban society, but has properties that are compatible with city people, that is civilized. Civil society by the United Nations is defined as a democratic society and respect human dignity or rights of responsibility. Paine, T. defines civil society as a space where citizens can develop their personality and provide opportunities for the satisfaction of interests freely and without coercion. In contrast to Paine A.S. Hikam describes civil society as organized areas of social life and is characterized by volunteerism, self-sufficiency and selfreliance, high independence towards the state, and attachment to the norms and legal values that its citizens follow.

\section{Features of Civil Society}

Civil society has its own character different from other types of society, among the characteristics of civil society are: 1) there is the order of values and social norms, 2) 
have a high civilization based on Qur'an and As-Sunnah, and can evidenced by science and technology, and has adab and manners to fellow human beings whose rules are derived from social norms and religious norms, 3) Having a free public space, where people can be closely connected with the implementation of the principles of consensus deliberation values. This public space enables people to express opinions that are guaranteed by law, 4) there is supremacy of law, where the law is placed in the highest position in the administration of government and is neutral and does not favor the interests of certain groups, 5) The existence of social participation that upholds high principle of mutual cooperation for the achievement of mutual interest. Of course, for the purpose of society to be achieved, there needs to be a harmony between rights and obligations.

\section{Characteristics of Civil Society}

Bahmueller argues that civil society has the following characteristics:

1. Individuals and groups are integrated through contact and social interaction.

2. The existence of an alternative power system that accommodates the interests that dominate society.

3. The existence of government-designed development programs that are harmonized with community-driven development programs.

4. Individual and state interests can be bridged by organizations that accommodate input to government decisions.

5. The creativity of the community develops even though it was initially hampered by the totalitarian regime's power.

6. Growing loyalty and trust that makes individuals recognize its relation to others and unselfishness.

7. People's freedom is shaded by social institutions that can accommodate multiple perspectives.

The above statement can be concluded that civil society has a polite behavior by being able to interact with each other both between individuals and groups. The community is united under a regulation that protects and protects its citizens, so the trust of the government is high. Public freedom is appreciated by the presence of social institutions that can accommodate a variety of perceptive. Examples of civil society in Islam are reflected in Surah Saba verse 15 which means as follows: "There was for (the tribe of) Saba' in their dwelling place a sign: two (fields of) gardens on the right and on the left. (They were told), "Eat from the provisions of your Lord and be grateful to Him. A good land (have you), and a forgiving Lord."

Allah decree in Saba 'verse 15 explains that earlier examples of civil society can be found in the Saba people, ie those who lived during the time of Solomon. Apart from the story of the Saba 'the civilization of civil society can also be obtained from the life of the people of Madinah when the signing of the Medina Treaty between the Prophet and the Medina Muslims with the Jewish population. The agreement contains an agreement that accommodates the needs of Muslim and Jewish communities so as to avoid any divisions that will occur. The existence of the rule of law that arranged the life of plural society in the city of Medina at that time is a reflection of the characteristics of civil society.

\section{CONCLUSIONS}

Changes in life that occur as a result of globalization include ideological aspects, political, economic, sociocultural, defense and security, making also behavioral changes for the people. Anticipation of the things that are not desirable need to be maximized. Technological stuttering can occur when the community, especially the younger generation who already know about the use of advanced products, but still minimal in ethics, then what happens is the use of technological products is not in place.

The role of parents is very important in educating children to become useful human beings for themselves and their communities, as it is said that the family is the first school for the child should be able to become the basic pantheon of education. TPQ is present to fulfill the role of parents in religious education. TPQ is expected to give more insight on reading Qur'an with the concept of the Garden which is based on Qur'an and As-Sunnah, and halaqah Ulama. Hope TPQ is able to build mentally the young generation become strong and sturdy in order to make them into the best generation. A healthy mental condition will certainly bring out normal individuals. A normal person is a form of individual behavior that does not deviate from the behavior in general where an individual is living, and a normal person will show the behavior of a harmonious and appropriate and acceptable to the public in general, where the attitude of his life in accordance with the norms and patterns living environment. In simple terms the individual is able to adapt naturally.

Good mentality is able to cultivate civil society that has the best character as able to understand and adhere to the noble values of society, and able to have a high civilization based on Qur'an and As-Sunnah, and have adab and manners to fellow human beings the rules are derived from social norms and religious norms.

\section{REFERENCES}

Qur'an

Ohmae, K., (1991) The Borderless World. New York: Harper Bussiness. 
Drijarkara, (1964), Pendidikan Filsafat. Jakarta: PT. Pembangunan

Undang-Undang Dasar 1945

Ubaedillah dan Abdul Rozak, (2008). Pendidikan Kewarganegaraan Edisi Ketiga (Demokrasi, Hak Asasi Manusia dan Masyarakat Madani). Jakarta: Penerbit Prenada Media Group.

Azyumardi, A., (2004). Menuju Masyarakat Madani. Bandung: PT Remaja Rosdakarya.

Kartini K. dan Jenny A. (1989). Hygiene Mental dan Kesehatan Mental dalam Islam. Bandung : Mandar Maju

Zakiyah D., (1990). Kesehatan Mental. Jakarta: CV Haji Masagung,

http://www.artikelsiana.com/2015/08/penegrtianmasyarakat-madani-ciri.html

http://documents.tips/documents.tips/documents/makalahmasyarakat-madani-55cac76e00af5.html

http://hakamabbas.blogspot.co.id/2014/01/pengertianmental.html 